\title{
Establishment of a new method for isolation and culture of equine endometrial epithelial and stromal cells
}

\author{
Tobias Theuß, Denny Böttcher, Alexander Kappe, Heinz-Adolf Schoon and Christin Ellenberger \\ Institute of Pathology, Faculty of Veterinary Medicine, University of Leipzig, Germany
}

\begin{abstract}
Summary
A new method of in vitro culture of equine endometrial epithelial and stromal cells is described. After dissection, the endometrial tissue was dissociated in collagenase type II, sieved through nylon gauze and the different cell types were separated by centrifugation and differential adhesion. Cells were seeded at a density of $1 \times 10^{4}$ viable cells per $\mathrm{cm}^{2}$ on several surfaces and cultured at $37^{\circ} \mathrm{C}$ in humidified atmosphere. For both cell types the same serum-supplemented culture medium was utilized whereby confluent monolayer evolved after 10 to 14 days of incubation. Confluent cultures were dissociated using $0.25 \%$ trypsin-EDTA (stromal cells) or alfazyme (epithelial cells) and passaged up to 19 times. Further on, a successful cryoconservation-protocol could be established. With it, we created the precondition to establish a co-culture system for equine endometrial epithelial and stromal cells with the long-term objective to study growth characteristics, effects of steroid hormones and mutual influences between the cell populations, as well as potential pathogenetic factors and etiological influences on equine endometrosis.
\end{abstract}

Keywords: cell culture, endometrium, epithelial cells, stromal cells, horse

\begin{abstract}
Etablierung einer neuen Methode zur Isolierung und Kultur equiner endometrialer Epithel- und Stromazellen
Eine neve Methode der in-vitro-Kultur equiner endometrialer Epithel- und Stromazellen wird beschrieben. Nach mechanischer Zerkleinerung der Proben erfolgte die enzymatische Auftrennung des Gewebes mittels Kollagenase Typ II, sowie die Trennung der verschiedenen Zellarten durch Filtration, Dichtegradientenzentrifugation und Differenzialadhärenz. Die Zellen wurden dann in einer Dichte von 1x104 lebenden Zellen pro $\mathrm{cm}^{2}$ auf verschiedene Wachstumsoberflächen ausgesät und in feuchter Umgebung bei $37^{\circ} \mathrm{C}$ kultiviert. Für beide Zellarten wurde dasselbe serumhaltige Nährmedium verwendet, womit die Kulturen nach 10 bis 14 Tagen in der Lage waren, konfluente Monolayer auszubilden. Diese wurden dann mittels $0.25 \%$-iger Trypsin-EDTA Lösung (Stromazellen) beziehungsweise Alfazyme (Epithelzellen) erfolgreich über bis zu 19 Passagen hinweg subkultiviert. Nicht passagierte Epithel- und Stromazellen wurden in flüssigem Stickstoff kryokonserviert und konnten zu späteren Zeitpunkten wieder der Kultur zugeführt werden. Damit wurden essenzielle Voraussetzungen für die Etablierung einer Kokultur equiner endometrialer Epithel- und Stromazellen geschaffen, auf deren Basis wiederum weitere Untersuchungen zur Pathogenese und Ätiologie der equinen Endometrose durchgeführt werden können.
\end{abstract}

Schlüsselwörter: Zellkultur, Endometrium, Epithelzellen, Stromazellen, Pferd

\section{Introduction}

In general, in vitro culture is an appropriate model to investigate the physiology, interaction and differentiation of different cell types under controlled and defined conditions (Freshney 1990), for the better understanding of the pathogenesis and the etiology of several diseases (Findlay et al. 1990). Because preliminary tests could be accomplished using this technique one can reduce the number of animal experiments, as well.

Up to now, numerous cell culture systems and protocols for isolation and culture of endometrial tissue from humans (Satyaswaroop et al. 1979, Mylonas et al. 2000) and several animals exist (Uchima et al. 1991, Ordener et al. 1993, Sheldrick et al. 1993, Piva et al. 1996, Groothuis et al. 2002, Sharma et al. 2002, Yamauchi et al. 2003). However, little was done to isolate and culture equine epithelial glandular cells and stromal cells (Watson et al. 1992, Brady et al. 1992, 1993, Day et al. 1998, Buschatz 2007).

The aim of the present work was therefore to establish and to improve a new cell culture system for equine endometrial epi- thelial (EEC) and stromal cells (ESC) in order to study the characteristics and growth of different cell types as well as influences due to selected steroid hormones, growth factors and/or hypoxia. Finally, this work shall provide a basis to create a co-culture system as an appropriate model to investigate the etiopathogenesis of equine endometrosis. This disease is one of the most important causes of sub- and infertility in mares. While several histological and in vivo studies were done, only parts of the pathogenesis are understood (Hoffmann et al. 2009) and the etiology, as well as possible aspects of treatment still remain unclear (Kenney 1978, Schoon et al. 1995, Hoffmann et al. 2009).

\section{Material and Methods:}

Animals

Endometrial tissue was obtained from adult gynecologically healthy mares by transcervical biopsy $(n=9)$. In two cases whole uteri from slaughtered mares were used for isolation 
and one culture was performed from the uterus of a mare that was euthanized due to severe recurrent airway obstruction.

The biopsy specimens were only applied to evaluate the technical procedure. Therefore the animals were not examined gynecologically in detail, but were healthy and had normal cyclic activity. Unfortunately, the exact day of the cycle of the three mares that donated the whole uteri could not be stated as well, given that all uteri were examined by the author at the time of necropsy, respectively after slaughtering. Clinical data regarding the ovarian cycle, especially the time of the last ovulation do not exist. The only available clinical information for the author was that all mares did not show any signs of gynecological diseases. Thus, we estimated the stage of the ovarian cycle on the basis of development and regression of follicles, corpora lutea and corpora haemorrhagica (Arthur 1958, VanNiekerk et al. 1973, 1975, Kenney et al. 1979) in comparison to routine histopathological examination of the endometrial tissue (Kenney and Doig 1986, Schoon et al. 1992, 1997).

Endometrial epithelial and stromal cells were isolated by a modified protocol according to the technique described by Buschatz (2007). All of the obtained biopsy specimens were collected as aseptically as possible, cut into pieces of $1.0 \mathrm{x}$ $0.5 \times 0.5 \mathrm{~cm}$ and placed into cold sterile $\mathrm{Ca} / \mathrm{Mg}$-free Hank s balanced salt solution (HBSS) (PAA Laboratories, Cölbe, Germany) containing 2 \% Antibiotic-Antimycotic Solution (AB) (PAA Laboratories, Cölbe, Germany) until they arrived at the laboratory. For preparation of endometrium from the whole uterus the surface of the organs was washed with HBSS, opened longitudinally at the corpus uteri and strips of about 2.0 $\times 0.7 \times 0.2 \mathrm{~cm}$ were dissected and separated from the myometrium using a disposable scalpel.

\section{Isolation}

After two washing steps in HBSS to remove remaining blood cells, debris or mucus the pieces were minced into fragments of about $1 \mathrm{~mm}^{3}$ and rinsed in HBSS again. The tissue was digested in collagenase solution containing collagenase type II (Biochrom AG, Berlin, Germany) in HBSS with $2 \% A B$ at $37{ }^{\circ} \mathrm{C}$ for 3 to 4 hours ( $5 \% \mathrm{CO}_{2}$ atmosphere). The tissue fragments were agitated continuously by a laboratory shaker and periodically by gentle, repeated pipetting to disrupt the cells and abbreviate the residence time of collagenase. In the third and fourth hour of the process the digestion progress was monitored every 30 to 45 minutes by decanting a drop of the solution on a microscopic slide and visualized by an inverted microscope (Olympus CK2, Olympus, Tokyo, Japan). When only a few ESC left adhering to the glands, the slurry was filtered through a nylon sieve, rinsed with warm Dulbeccos modified Eagles medium (DMEM)/Ham s F-12 (PAA Laboratories, Cölbe, Germany) and the arising ESC were centrifuged on a Percoll solution (Amersham Biosciences, Uppsala, Sweden) with $400 \times \mathrm{g}$ for 20 minutes (Buschatz 2007). The remaining EEC on the gauze were rinsed and afterwards centrifuged on a Percoll gradient (Buschatz 2007) as well. The average cell yield was determined using a Neubaver counting chamber. To avoid higher grades of cross-contamination (more than $5 \%$ ), differential adherence was also performed with each cell type.
Non-cultured cells from each type were fixed in $4 \%$ neutral buffered formalin, pelletised and embedded in paraplast for immunocytochemistry.

\section{Culture}

The isolated cells were allowed to grow in DMEM/Ham s F12 , supplemented with $2.5 \%$ foetal bovine serum (FBS), $1 \%$ $A B, 0.275 \%$ Amphotericin B, $1 \%$ ITS (insulin, transferrin, selenium), 1 \% HEPES-Buffer (all obtained from PAA Laboratories, Cölbe, Germany), $8 \mathrm{ng} / \mathrm{ml}$ epidermal growth factor (human, E. coli) (Biochrom AG, Berlin, Germany) and 0.5 $\mu \mathrm{g} / \mathrm{ml}$ hydrocortisone (Sigma-Aldrich, Steinheim, Germany). Cells were plated at a density of $1 \times 10^{4}$ viable cells per $\mathrm{cm}^{2}$ (trypan-blue exclusion method) (trypan blue, Sigma Aldrich, Taufkirchen, Germany) in culture flasks, 6-/12-/24-well plates (Becton Dickinson, Franklin Lakes, New Jersey, USA), Millicell ${ }^{\circledR}$ PCF culture inserts $(12 \mathrm{~mm}, 3.0 \mu \mathrm{m}$ pores, Millipore, Bedford, USA), Chamber Slides ${ }^{T M}$ (Nalge Nunc International, NY, USA) or cover slips (Carl Roth GmbH, Karlsruhe, Germany) and maintained to confluence at $37{ }^{\circ} \mathrm{C}$ in a humidified atmosphere containing $5 \% \mathrm{CO}_{2}$. In general, the medium was changed every two days. Sole exception were the epithelial cells remaining in the medium, they were seeded in for the first four days of culture (primary and following passages). Thereafter, they were handled in the same manner than the ESC.

\section{Subculture}

Confluent cultures were passaged from culture flasks by the following protocols depending on the cell type. Twice rinsing with warm HBSS was followed by an enzymatic detachment with alfazyme (EEC) (PAA Laboratories, Cölbe, Germany) and $0.25 \%$ trypsin-EDTA (ESC) (Biochrom AG, Berlin, Germany) in HBSS, both at $37{ }^{\circ} \mathrm{C}$ in humidified atmosphere. Epithelial cultures needed a reaction time up to 45 minutes, whereas stromal cells already detached within 5 to 10 minutes. The appropriate enzyme was blocked with an equal amount of FBS-supplemented culture medium and centrifuged at $100 \mathrm{x}$ $\mathrm{g}$ for 15 minutes to segregate the used enzyme. Afterwards, the arising cell pellet was dispersed in culture medium and the cells seeded at the same density than in primary culture. However, for the first three passages, epithelial cells had to be seeded at higher density to achieve satisfactory results. As aforementioned, non-cultured cells were embedded in paraplast for immunocytochemistry (Böttcher et al. 2010), as well.

\section{Cryopreservation}

Cryopreservation was performed with both EEC and ESC according to the sub cultivation protocol described above. The generated pellet from one culture flask was resolved in 1 $\mathrm{ml}$ of culture medium and mixed with the same amount of cryomedium, containing $40 \%$ FBS, $40 \%$ culture medium and $20 \%$ dimethyl sulfoxide (DMSO) (Carl Roth GmbH, Karlsruhe, Germany) as preservative agent. Vials of $1 \mathrm{ml}$ volume were frozen at $-80{ }^{\circ} \mathrm{C}$ for 24 hours and afterwards stored in liquid nitrogen. Depending on the cell type each vial contained approximately $1 \times 10^{4}$ stromal and $4 \times 10^{5}$ epithelial cells. 
Cryopreserved cells were thawed in a heating bath at $37{ }^{\circ} \mathrm{C}$, mixed with $3 \mathrm{ml}$ of warm culture medium followed by centrifugation with $100 \times \mathrm{g}$ for 15 minutes. In general, two $25 \mathrm{~cm}^{2}$ culture flasks were charged from one vial and allowed to grow to confluence.

Cryomedium was evaluated using the stromal cell population. For this purpose, half of a cell population was frozen at $-196{ }^{\circ} \mathrm{C}$ in DMSO-containing cryomedium prior seeding in a 6-well plate (density $1 \times 10^{4}$ cells per well). Then, growth rate was assigned in comparison to non-frozen cultures (control) seeded at the same density, every second day by trypsinization and counting in a Neubaver counting chamber (trypan-blue exclusion method) until the cultures reached confluence. At a later date, epithelial cells from subculture 11 were frozen likewise, but seeded at a higher density $\left(4 \times 10^{5}\right.$ per culture flask) and were cultivated to confluence.

\section{Visualization}

Cultures were inspected for growth, morphology and crosscontamination every two days on an inverted microscope. In addition, confluent cultures grown on Chamber Slides ${ }^{T M}$ or cover slips were fixed for 10 minutes in pure methanol prior the staining with Giemsa, haemalaun and eosin (H.-E.) and alcian blue (Romeis 1989) for microscopic examination.

\section{Results}

Routine histopathological examination of the endometrial tissue from the whole uteri showed that one mare was in the transition from proliferatory to secretory phase, while the others were in the early secretory phase. In addition to the findings in the ovaries of each mare (unilateral one Corpus luteum, respectively Corpus haemorrhagicum and on every ovary multiple small follicles and Corpora albicantia), we stated two mares to be in the interoestrus and one to be postovulatory.

Light microscopic examination during the culture period of primary isolated and subcultured endometrial cells pointed out that stromal and epithelial cells differed in morphology. Cross-contamination was judged by light microscopy to be less than $5 \%$. Whereas ESC came out of the isolation process as single cells, the EEC were seeded in as glands with up to 200 cells per cluster.

The stromal cells were spindle to star shaped during the first days of culture and grew to confluent monolayers revealing typical fibroblast-like morphology in the following period including subculture (Fig. 1).

EEC glands collapsed and flattened after adhesion on the growth surface and started to grow out radially from each cluster. Even in the following subculture, two different types of epithelial cells could be observed: small (up to $10 \mu \mathrm{m}$ in diameter) polygonal cells with distinct and regular borders growing in clusters with up to 100 cells, and larger (up to $50 \mu \mathrm{m}$ in diameter) polyhedral, occasionally multinucleated cells with irregular and indistinct borders lain in groups containing up to 20 cells (Figs. 2 and 3).
The morphology of the cultured cells revealed comparable results in every primary and following subculture independently from the origin of the material.

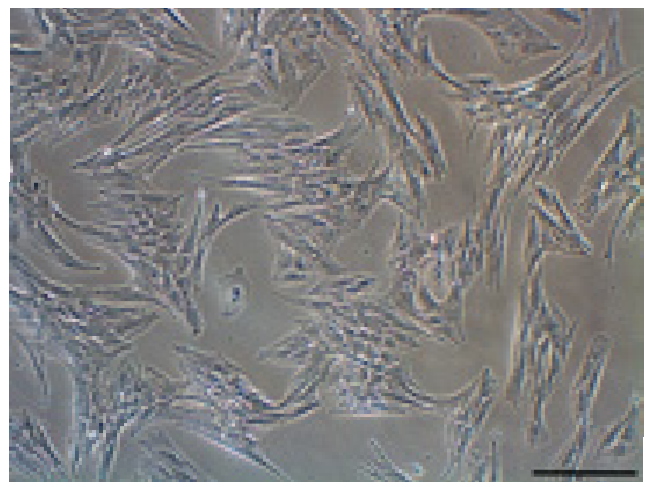

Fig. 1 Stromal cells growing on plastic on day 6 of culture revealing typical fibroblast-like morphology, phase contrast, bar $50 \mu \mathrm{m}$. Stromazellen auf Plastikoberfläche am 6. Kulturtag mit typischer Fibroblasten-ähnlicher Morphologie, Phasenkontrast, Balken $50 \mu \mathrm{m}$.

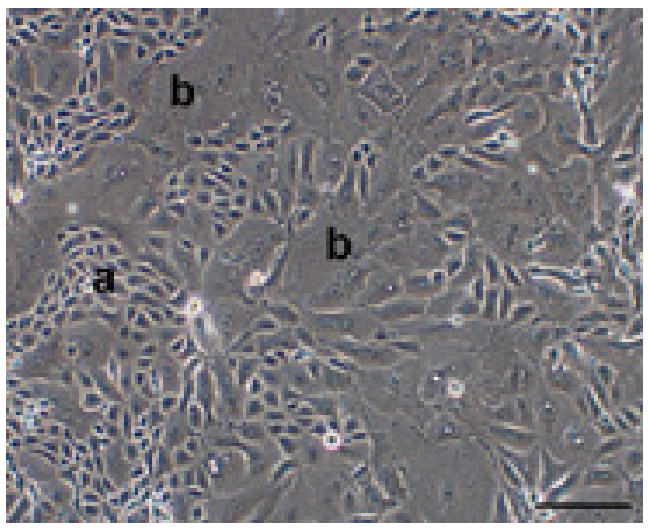

Fig. 2 Epithelial cells growing on plastic, small polygonal cells with regular and distinct borders (a), larger polyhedral cells with irregular borders (b), passage 10, day 6 of culture, phase contrast, bar $50 \mu \mathrm{m}$. Epithelzellen auf Plastikoberfläche, kleine polygonale Zellen mit regulären und deutlichen Zellgrenzen (a), größere polyedrische Zellen mit irregulären Zellgrenzen (b), Passage 10, 6. Kulturtag, Phasenkontrast, Balken $50 \mu \mathrm{m}$.

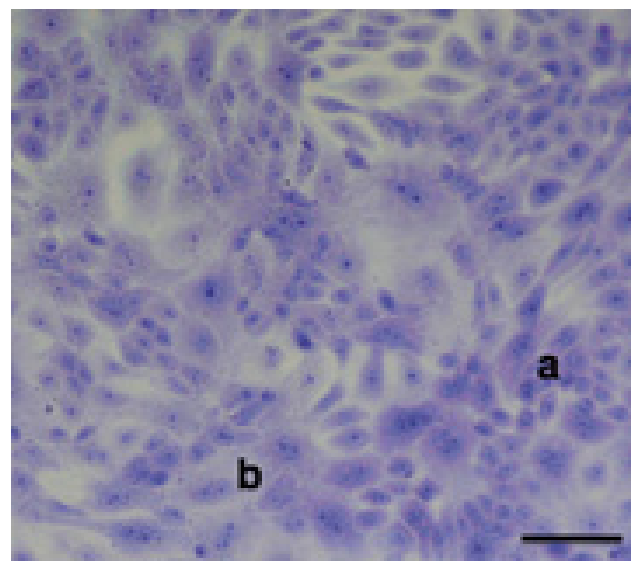

Fig. 3 Epithelial cells growing on Chamber Slides ${ }^{T M}$, small polygonal cells with regular and distinct borders (a), bigger polyhedral cells with irregular borders (b), passage 12, day 6 of culture, Giemsa, bar $100 \mu \mathrm{m}$

Epithelzellen auf Chamber Slides ${ }^{T M}$, kleine polygonale Zellen mit regulären und deutlichen Zellgrenzen (a), größere polyedrische Zellen mit irregulären Zellgrenzen (b), Passage 12, 6. Kulturtag, Giemsa, Balken $100 \mu \mathrm{m}$. 
Viability of primary isolated cells depended directly on the time elapsed from preparation of the tissue to further processing in the laboratory. Biopsy specimens were usually taken in close proximity to our institute providing high viability, but fewer numbers of average cell counts, due to limited material. On the contrary, whole uteri yielded disproportionately more cells, but either they could only be obtained from slaughter houses farther away or during necropsy both prospects took more time from the point of death of the horse to tissue preparation with decreased numbers of viable cells.

Subculture of stromal cells could be accomplished in this study without any challenge. However, subculture of epithelial cells revealed no satisfying results as cultures were increasingly contaminated with ESC. In case of absence of stromal cells, passages up to 19 times and more were possible without any changes in proliferation rate, growth behaviour and morphology (Figs. 2 and 3).

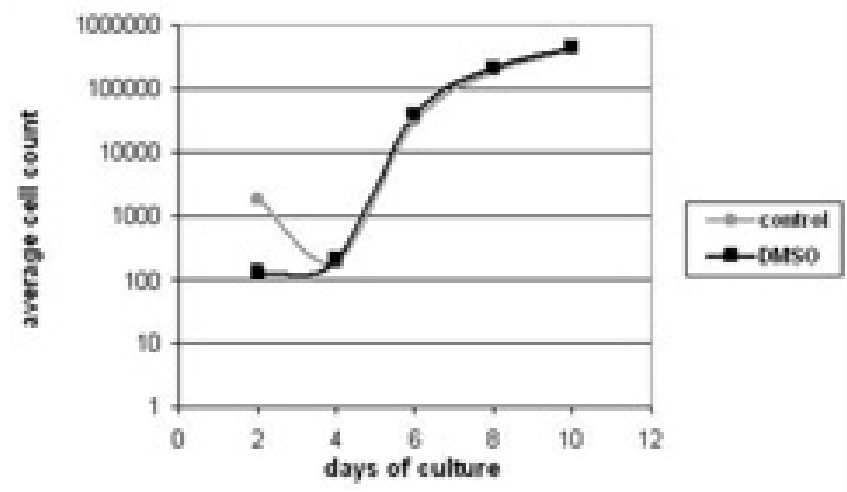

Fig. 4 Average cell count of ESC frozen in DMSO-supplemented cryomedium (DMSO) compared to non-frozen ESC (control), assigned every second day.

Mittlere Zellzahl an ESC, welche in DMSO-haltigem Kryomedium (DMSO) eingefroren wurden, im Vergleich zu nicht kryokonservierten Stromazellen (control). Die Bestimmung erfolgte an jedem zweiten Kulturtag.

As pointed out in Fig. 4, cell count of cryopreserved and conventionally seeded ESC decreased until day 4 and accelerated in the same manner the following days, until DMSOgroup and control were confluent on day 10. Epithelial cells from subculture 11 which were frozen likewise, reached confluence after 10 days of culture.

\section{Discussion}

Isolation and culture of equine endometrial epithelial and/or stromal cells has previously been described only by a handful of authors (Watson et al. 1992, Brady et al. 1992, 1993, Burghardt et al. 1995, Day et al. 1998, Buschatz 2007). The morphology of EEC and ESC cultured in this study reveal matchable results compared to the findings in other species (women and animals) (Satyaswaroop et al. 1979, Ricketts et al. 1983, Zhang et al. 1991) and the mare (Watson et al. 1992, Buschatz 2007) without the prejudice of the usage of a serum-reduced culture medium.
As indicated by several authors, for example Gruenert et al. (1995) and Shibeshi et al. (2008), removal of fibroblasts (stromal cells) is a key factor for establishing long-term primary epithelial cultures and sub cultivation. For this purpose, two possible procedures exist: on one hand selective removal of fibroblasts by magnetic cell sortening or antibody mediated complement reaction (Singer et al. 1989) and on the other hand differential cell adhesion. In addition, serum-free (or at least serum-reduced) culture medium can suppress the growth of remaining stromal cells. Given that the aforementioned procedures require higher amounts of technical equipment and are proved not suitable for equine fibroblasts (Shibeshi et al. 2008), this study focused on the development of a serum-reduced culture medium, a gentle detachment and adapted subculture. In combination with the formerly described method by Buschatz (2007) this resulted in high pureness of cell lines ( $<5 \%$ cross-contamination), the suitability of the same culture medium for EEC and ESC and further on the possibility of sub cultivation and cryopreservation. For this reason, we created the precondition to establish a co-culture system for both primary culture and subculture (for example as described by Arnold et al. 2001 and Lu et al. 2008) with the long-term objective to study growth characteristics, effects of steroid hormones and mutual influences between the cell populations, as well as potential pathogenetic factors and etiological influences on equine endometrosis.

\section{Acknowledgements}

This work was supported financially by the "Ernst von WeberStiftung". We are also grateful to the personnel from the "Large Animal Clinic for Theriogenology and Ambulatory Services" of the University of Leipzig for sample collection.

\section{References}

Arnold J. T., Kaufman D. G., Seppälä M. and Lessey B. A. (2001) Endometrial stromal cells regulate epithelial cell growth in vitro: a new co-culture model. Hum Reprod. 16, 836-45

Arthur G. H. (1958) An Analysis of the Reproductive Function of Mares Based on Post-mortem Examination. Vet Rec. 70, 682-5

Brady H. A., Burghardt R. C., Evans J. W., Blanchard T. L. and Varner D. D. (1992) Intercellular Communication in Mare Endometrial Epithelium Isolated During Estrus and Diestrus. J. Equine Vet. Sci.. $12,227-232$

Brady H. A., Burghardt R. C., Evans J. W., Blanchard T. L., Varner D. D. and Bruemmer J. E. (1993) Model System for the Study of Uterine Trophoblast Interactions in the Mare. J. Equine Vet. Sci. 13, 506-511

Böttcher D., Theuß T., Kappe A., Sobirai A., Schoon H.-A. and Ellenberger C. (2010) Morpho-functional characterization of equine endometrial epithelial cells in vitro - preliminary results. Pferdeheilkunde, in press

Burghardt R. C., Barhoumi R., Sewall T. C. and Bowen J. A. (1995) Cyclic AMP induces rapid increases in gap junction permeability and changes in the cellular distribution of connexin43. J. Membr. Biol. 148, 243-53

Buschatz S. (2007) Etablierung und Charakterisierung einer Zellkultur equiner endometrialer Epithel- und Stromazellen. Dissertation med. vet. Univ. Leipzig

Day W. E., Bowen J. A., Barhoumi R., Bazer F. W. and Burghardt R. C. (1998) Endometrial connexin expression in the mare and pig: evidence for the suppression of cell-cell communication in uterine luminal epithelium. Anat. Rec. 251, 277-285 
Findlay J. K., Salamonsen L. A. and Cherny R. A. (1990) Endometrial function: studies using isolated cells in vitro. Oxf. Rev. Reprod. Biol. 12, 191-223

Freshney R. I. (1990) Tierische Zellkulturen. Berlin, New York: de Gruyter; p. 2-3

Groothuis P. G., McGuire W. J., Vallett J .L., Grieger D. M. and Davis D. L. (2002) Retinol and estradiol regulation of retinol binding protein and prostaglandin production by porcine uterine epithelial cells in vitro. J. Anim. Sci. 80, 2688-2694

Gruenert D. C., Finkbeiner W. E. and Widdicombe J. H. (1995) Culture and transformation of human airway epithelial cells. Am. J. Physiol. 268, L347-L360

Hoffmann C., Ellenberger C., Mattos R. C., Aupperle H., Dhein S. and Stief B. (2009) The equine endometrosis: new insights into the pathogenesis. Anim. Reprod. Sci. 111, 261-278

Kenney R. M. (1978) Cyclic and pathologic changes of the mare endometrium as detected by biopsy, with a note on early embryonic death. J. Am. Vet. Med. Assoc. 172, 241-62

Kenney R. M. and Doig P. A. (1986) Equine Endometrial Biopsy. In: Morrow D.A., editor. Current Therapy in Theriogenology. 2nd. Edit. Philadelphia: WB Saunders; p. 723-729

Lu S. H., Wang H. B., Liu H., Wang H. P., Lin Q. X. and Li D. X. (2008) Reconstruction of Engineered Uterine Tissues (EUTs) Containing Smooth Muscle Layer in Collagen/Matrigel Scaffold In Vitro. Tissue Eng Part A. 15, 1611-1618

Mylonas I., Speer R., Makovitzky J., Richter D. U., Briese V. and Jeschke U. (2000) Immunohistochemical analysis of steroid receptors and glycodelin A (PP14) in isolated glandular epithelial cells of normal human endometrium. Histochem. Cell. Biol. 114, 405-411

Ordener C., Cypriani B., Vuillermoz C. and Adessi G. L. (1993) Epidermal growth factor and insulin induce the proliferation of guinea pig endometrial stromal cells in serum-free culture, whereas estradiol and progesterone do not. Biol. Reprod. 49, 1032-1044

Piva M., Flieger O. and Rider V. (1996) Growth factor control of cultured rat uterine stromal cell proliferation is progesterone dependent. Biol. Reprod. 55, 1333-1342

Ricketts A. P., Hagensee M. and Bullock D. W. (1983) Characterization in primary monolayer culture of separated cell types from rabbit endometrium. J. Reprod. Fertil. 67, 151-60

Romeis B. and Böck P. (1989) Mikroskopische Technik. 17th ed. München: Urban und Schwarzenberg; p. 235, 474-475,443-444

Satyaswaroop P. G., Bressler R. S., de la Pena M. M. and Gurpide E. (1979) Isolation and culture of human endometrial glands. J. Clin. Endocrinol Metab. 48, 639-641

Schoon H.-A., Schoon D. and Klug E. (1992) Uterusbiopsien als Hilfsmittel für Diagnose und Prognose von Fertilitätsstörungen der Stute. Pferdeheilkunde. 8, 355-362

Schoon H.-A., Schoon D., Kötter B., Runge A. and Klug E. (1995) Zu Pathogenese und Prognose der Endometrose der Stute. In: Deutsche Veterinärmedizinische Gesellschaft, editor. Bericht des 21. Kongresses der Deutschen Veterinärmedizinischen Gesellschaft e.V., 1995 Mar 21, Bad Nauheim, p. 273-282
Schoon H.-A., Schoon D. and Klug E. (1997) Die Endometriumsbiopsie bei der Stute im klinisch-gynäkologischen Kontext. Pferdeheilkunde 13, 453-464

Sharma R., Srivastava S., Baipai V. K. and Balapure A. K. (2002) Histological and ultrastructural regulation in rabbit endometrial explants by estrogen in serum-free culture. In Vitro. Cell. Dev. Biol. Anim. 38, 293-297

Sheldrick E. L., Flick-Smith H. C. and Dos Santos Cruz G. J. (1993) Oxytocin receptor binding activity in cultured ovine endometrium. J. Reprod. Fertil. 98, 521-528

Shibeshi W., Abraham G., Knever C., Ellenberger C., Seeger J. and Schoon H.-A. (2008) Isolation and culture of primary equine tracheal epithelial cells. In Vitro Cell Dev. Biol. Anim. 44, 179-184

Singer K. H., Scearce R. M., Tuck D. T., Whichard L. P., Denning S. M. and Haynes B. F. (1989) Removal of fibroblasts from human epithelial cell cultures with use of a complement fixing monoclonal antibody reactive with human fibroblasts and monocytes/macrophages. J. Invest. Dermatol. 92, 166-170

Uchima F. D., Edery M., Iguchi T. and Bern H. A. (1991) Growth of mouse endometrial luminal epithelial cells in vitro: functional integrity of the oestrogen receptor system and failure of oestrogen to induce proliferation. J. Endocrinol. 128, 115-120

Van Niekerk C. H., Gerneke W. H. and van Heerden J. S. (1973) Anatomical and histological observations on the reproductive tract of mares with abnormal oestrous cycles. J. S. Afr. Vet. Assoc. 44, $141-152$

VanNiekerk C. H., Morgenthal J. C. and Gerneke W. H. (1975) Relationship between the morphology of and progesterone production by the corpus luteum of the mare. J. Reprod. Fertil. Suppl. 23, $171-175$

Watson E. D., Aubrey E. S., Zanecosky H. G. and Sertich P. L. (1992) Isolation and culture of glandular epithelial and stromal cells from the endometrium of mares. J. Reprod. Fertil. 95, 269-275

Yamauchi N., Yamada O., Takahashi T., Imai K., Sato T. and Ito A. (2003) A Three-dimensional Cell Culture Model for Bovine Endometrium: Regeneration of a Multicellular Spheroid Using Ascorbate. Placenta 24, 258-269

Tobias Theuß

Institut für Veterinär-Pathologie

Universität Leipzig

An den Tierkliniken 33

04103 Leipzig, Germany

theuss@vetmed.uni-leipzig.de 